\title{
Growth responses of yearling Yankasa rams to four different hays and concentrate
} supplementation

${ }^{1 *}$ Ogedegbe, S.A., ${ }^{1}$ Ahmed, A. and ${ }^{2}$ Imasuen, J A.

${ }^{1}$ Livestock Investigation Department, National Veterinary Research Institute, PMB 1, Vom Plateau State. ${ }^{2}$ Department of Animal Science, University of Benin, PMB 1154, Benin City, Edo State *Corresponding author: sundayogedegbe@gmail.com, new address: Department of Crop Science University of Benin, PMB 1154, Benin City, Edo State

\section{Abstract}



The objective of the study was to ascertain the feed intake, acceptability of hay and weight gain by yankasa rams fed basal diets of either natural grass hay (NGH) as control, Digitaria exilis hay $(D E H)$, Bracharia decumbens hay $(B D H)$ or Digitaria decumbens hay (DDH) along with equal amounts of concentrate feed as supplement. The 10-week experiment was conducted at the College farm of the National Veterinary Research Institute (NVRI), Vom, Plateau State, Nigeria using Completely Randomized Design. The four hays were allotted randomly to twenty rams housed in separate pens. There were five rams per treatment. Each animal was served $2 \mathrm{~kg}$ of the hay treatment, plus $200 \mathrm{~g}$ concentrate supplement. The parameters measured were feed intake (FI), water consumed $(W C)$, hay acceptability $(H A)$, weekly weight $(W W)$, total weight gained (TWG) and daily weight gain (DWG) by rams. Hay treatment affected weekly weight of yankasa rams significantly. Daily weight gain was 142.9, 60.7, 42.9 and $10.7 \mathrm{~g}$ per day for rams fed with BDH, DDH, DEH and NRH, respectively. At week 10, rams fed with $B D H$ were significantly heavier by $78.0 \%$ than rams fed NGH and heavier by $33.2 \%$ on aggregate than rams fed with DEH and DDH. Total weight gain of rams fed BDH was $809.1 \%$ higher than TWG of animals fed with the control (NGH) treatment. Yankasa rams consumed 2.5 litres of water per head daily. The rams consumed significantly more of the natural grass hay (NGH) than the other hays. Acceptability of NGH, DEH and BDH was similar but DDH was not well accepted by rams. The great prospects of Bracharia decumbens hay for fattening yankasa rams, warrants expansion of this grass by NVRI.

Keywords: Weight gain, yankasa rams, hay, feed intake, Vom, Nigeria

\section{Introduction}

Sheep (Ovis aries) like other small ruminants consumes over $80 \%$ of its required dietary intake as forage from pasture, hay, silage and browse shrubs (Johnston, 1983). Sheep may be grazed along with large ruminants although many small scale producers fatten rams to slaughter weight under zero-grazing (confinement) to coincide with festive periods in Nigeria. The yankasa breed of sheep can attain a size of $25-45 \mathrm{~kg}$ for adult male and $25-35 \mathrm{~kg}$ for adult female (Whyte et al., 2001). Under confinement, various forages are fed in mixtures or as sole diets to sheep. Feed resources available to small holder farmers in the tropics include range forage, crop residues and agro-industrial by products (Finangwai et al., 2010). However, when forages are fed in mixtures to livestock, it is difficult to ascertain which forage specie is the best contributor to weight gain. If the best forages are not ascertained, it will be difficult to make recommendation for multiplication of species. Consequently, forage agronomists may establish the wrong pasture or stifle the right pasture. Knowledge of the quality and quantity of pasture produced and feed consumed is important in assessing nutrition and productivity of ruminant animals (Olubajo and Oyenuga, 1974). 
At the National Veterinary Research Institute (NVRI), Vom, Plateau State, Nigeria, pasture development was initiated by management to improve livestock productivity. Bracharia decumbens (Signal grass) and Digitaria decumbens (Pangola grass) were established for ruminant nutrition. The pastures are grazed, cut and carried and also made into hay for feeding livestock. Prior to establishment of these pastures, hay from annual grass Digitaria exilis (Acha grass) which is commonly available in Vom, in combination with hay from natural rangeland (Natural grass) formed the bulk of dry season feed for sheep at NVRI. Due to an increase in number of available hays, it is necessary to evaluate and ascertain their palatability to sheep and suitability for fattening sheep. The primary objective of the study was to ascertain the response of yankasa rams to four hays in terms of feed intake, weight gain and hay acceptability.

\section{Materials and Methods}

The 10-week feeding trial was conducted between $9^{\text {th }}$ May and $31^{\text {st }}$ July 2010 at the College farm of the National Veterinary Research Institute (NVRI), Vom, Plateau State, Nigeria. The farm is located on latitude $08^{\circ} 45^{\prime} \mathrm{E}$ and longitude $09^{\circ} 43^{\prime} \mathrm{N}$ at an altitude of $1239.4 \mathrm{~m}$ above sea level. The mean annual temperature and mean annual rainfall of the area were $20.8^{\circ} \mathrm{C}$ and 1400 $\mathrm{mm}$, respectively. The area has a marked dry season between November to May. The hays evaluated in the study were produced in the 2009 hay making season and stored in the hay barn under natural conditions prior to the experiment. Bracharia decumbens, Digitaria decumbens and Natural grass received no fertilizer application whereas Digitaria exilis was treated with $50 \mathrm{~kg} \mathrm{~N}$ ha1 of urea. Concentrate feed produced routinely at the NVRI farm was used to supplement the hay feed (Chest-Worth, 2002). Proximate analysis of the feeds was carried out according to the standard methods (AOAC, 2000). The percent crude protein $(\mathrm{CP})$, percent ether extract (EE) and percent nitrogen free extract (NFE) concentrations were used to compute metabolisable energy (ME) of the feeds (Lolum personal communication), using the following formulae: $\sum$ ( $\% \mathrm{CP} \times 4.1+\%$ EE $\times 9.3+\%$ NFE $\times 3.75)=$ ME $(\mathrm{kcal} 100 \mathrm{~g}$ ${ }^{1}$ ) (Maynard,1944) which was converted to $\mathrm{MJ} \mathrm{kg}^{-1}$.

Four hays (Bracharia decumbens (BDH), Digitaria decumbens (DDH), Digitaria exilis (DEH) and Natural grass (NRH) which served as control) comprised the treatments fitted into a Completely Randomized Design (CRD) and replicated five times. There were five animals in each treatment group giving a total of 20 animals under study. Each animal served as a replicate and was housed in a separate pen. The 20 yearling rams of Yankasa breed of sheep were obtained from the flock at the College farm. Average body weight and age of the rams before experimentation was 13 $\mathrm{kg}$ and 4 months, respectively. The animals were injected with vitamins A, D3 and E supplements and also treated with ivomec suspension against external and internal parasites two weeks before the experiment began. In addition, all animals had been previously vaccinated against PPR (Pest de Pestes Ruminants) disease. The animals were placed on a combination of the experimental diets for acclimatization a week before the experiment commenced.

At the onset of the trial, each animal was weighed with a Kenwood model 796 industrial scale to obtain initial weight which was recorded. Subsequently, each animal was supplied with $2 \mathrm{~kg}$ of hay depending on treatment, $200 \mathrm{~g}$ of 
concentrate and 4 litres of untreated pipe borne water over the duration of study. Left over feed and water were removed from the troughs measured and recorded before the next day ration was provided. Six parameters were measured in the experiment. Weekly weight (WW) for each animal was measured for 10 weeks by weighing on a scale. Total weight gained (TWG) was computed as the difference between WW at 10 weeks and initial weight

of each animal, Daily weight gain (DWG) was computed by dividing TWG (g) by 70 days. Feed intake (FI), water consumed (WC) and hay acceptability (HA) were recorded daily. Feed intake was computed as the difference between feed offered and feed left over. Hay acceptability was scored visually, as 3, 2, or 1 based on the quantity of hay left over by an animal (Kallah, personal communication), such that 3 represented high, 2 medium and 1 low acceptability of hay. The data compiled were subjected to analysis of variance (ANOVA) using the SAS (Statistical Analysis System) software package version 9.0 (SAS, 2002). The means were separated with the Least Significant Difference (LSD) method described by Steel and Torrie (1997).

\section{Results}

The composition of concentrate fed to Yankasa rams is presented in Table 1. Maize $(46.88 \%)$ constituted the single largest portion, followed by appreciable quantities of wheat offal $(21.87 \%)$ and cotton seed cake $(20.84 \%)$. Other ingredients in the formulation were rice offal $(5.73 \%)$, bone meal (2.08 \%), limestone (2.08\%), premix $(0.26 \%)$ and salt $(0.26 \%)$. Among the hays, natural grass hay produced the lowest $\mathrm{CP}$ $(1.4 \%)$ concentration while Digitaria exilis hay had the highest CP $(5.4 \%)$ content which was $285.7,31.7$ and $10.2 \%$ higher
Table 1: Composition (\%) of Concentrate fed to Yankasa rams

\begin{tabular}{lr}
\hline Ingredient & \% \\
\hline Maize & 46.88 \\
Cotton seed cake & 20.84 \\
Wheat offal & 21.87 \\
Rice offal & 5.73 \\
Bone meal & 2.08 \\
Limestone & 2.08 \\
Premix & 0.26 \\
Salt & 0.26 \\
\hline & 100.00 \\
\hline
\end{tabular}

than the $\mathrm{CP}$ values of $\mathrm{NGH}, \mathrm{BDH}$ and $\mathrm{DDH}$, respectively (Table 2). Natural grass hay with NFE value of $58.3 \%$ produced the highest while Digitaria decumbens hay with a value of $49.4 \%$ exhibited the lowest value. In addition, $\mathrm{BDH}$ had the highest ash $(14.3 \%)$ whereas NRH had the highest CF (30.4\%) concentrations. The metabolisable energy (ME) of the feeds fell within the range of 9.0-15.7 $\mathrm{MJ} \mathrm{kg} \mathrm{kg}^{-1} \mathrm{DM}$ with Digitaria decumbens at the lower end and concentrate feed at the upper end of the range (Table 1). The concentrate which had the highest crude protein $(\mathrm{CP})(29.2 \%)$ and ether extract (EE) $(8.9 \%)$ concentrations had the lowest nitrogen free extract (NFE) (46.8\%), ash (6.8\%) and crude fibre (9.2 $\%$ ) concentrations among the feeds (Table 2).

Effect of hay on feed intake (FI), hay acceptability (HA), total weight gained and daily weight gain was highly significant (Table 3). In terms of FI, animals consumed significantly $(\mathrm{p}<0.01)$ less pangola hay than the other hays. In the same vein, hay acceptability (HA) by rams was similar for natural grass, acha and signal hays, but significantly $(\mathrm{p}<0.01)$ lower for pangola hay. Yankasa rams consumed similar quantities of water irrespective of the hay 
Table 2: Proximate composition and Metabolisable energy (ME) value of concentrate and hays fed to experimental animals

\begin{tabular}{lcccccc}
\hline Feed & CP (\%) & EE (\%) & NFE (\%) & Ash (\%) & CF (\%) & ME (MJ kg \\
\hline Concentrate & DM) \\
Natural rangeland hay & 29.2 & 8.9 & 46.8 & 6.8 & 9.2 & 15.7 \\
Digitaria exilis hay & 1.4 & 1.1 & 58.3 & 6.9 & 30.4 & 9.8 \\
Bracharia decumbens hay & 5.4 & 1.7 & 55.9 & 9.7 & 27.3 & 10.4 \\
Digitaria decumbens hay & 4.9 & 1.1 & 53.1 & 14.3 & 27.4 & 9.5 \\
\hline CP= Cri & 1.1 & 49.4 & 7.3 & 37.3 & 9.0 \\
\hline
\end{tabular}

$\mathrm{CP}=$ Crude protein, $\mathrm{EE}=$ Ether extract, $\mathrm{NFE}=$ Nitrogen free extract, $\mathrm{CF}=$ Crude fibre, $\mathrm{ME}=$ Metabolisable energy

treatment (Table 3). The effect of hay on total weight gained and daily weight gain was a mirror image of each other in terms of statistical significance. Signal hay produced the significantly $(\mathrm{p}<0.01)$ highest values for both parameters (Table $3)$. Weekly weight of yankasa rams was significantly affected by hay (Table 4$)$. At weeks 2, 68 and 10, yankasa rams fed on Signal grass hay were significantly $(\mathrm{p}<$ 0.05 ) heavier than those fed on the natural grass hay (control) by $54.8 \%, 46.9 \%, 61.0$ $\%$ and $78.0 \%$ respectively. Moreover, at week 10 , rams fed signal grass hay were significantly $(\mathrm{p}<0.05)$ heavier than rams fed on the other hays while rams fed pangola and acha hays exhibited statistically similar weight. In addition, at week 10, natural grass hay produced rams with the significantly $(\mathrm{p}<0.01)$ lightest weights. Figure 1 shows that the weight gain by rams fluctuated across treatments over the course of experimentation.
However, differences in weight were not statistically significant at week 4 . Figure 2 depicts that average weekly water consumption by rams, dropped as the experiment progressed.

Discusssion

Collectively, hays fed to the rams were of good quality having furnished metabolisable energy (ME) values of 9.010.4 MJ kg ${ }^{-1}$ DM (Johnston, 1983). Technically, poor quality roughages have ME value of $7.5 \mathrm{MJ} \mathrm{kg}^{-1} \mathrm{DM}$ or lower and cereals of high quality possess ME value above $13 \mathrm{MJ} \mathrm{kg}^{-1} \mathrm{DM}$ (Cooper and Thomas, 1986). This infers that both the old (NRH and $\mathrm{DEH}$ ) and new (BDH and $\mathrm{DDH})$ hays evaluated in the current study can suitably provide required energy $\left(857 \mathrm{kcal} \mathrm{kg}^{-1}\right.$ i.e. $3.7 \mathrm{MJ} \mathrm{kg}^{-1}$ ) for sheep growth (Adu et al., 1974). However, the CP concentration of the NRH was drastically low. This connotes that rams fed solely on NRH would require

Table 3: Effect of hay on feed intake (kg), water consumed (litres), hay acceptability, total weight gained $(\mathrm{kg})$ and daily weight gain (g/day) of yearling Yankasa rams.

\begin{tabular}{|c|c|c|c|c|c|}
\hline Hay & $\begin{array}{l}\text { Feed } \\
\text { intake (kg) }\end{array}$ & $\begin{array}{l}\text { Water } \\
\text { consumed } \\
\text { (litres) }\end{array}$ & $\begin{array}{l}\text { Hay } \\
\text { acceptability }\end{array}$ & $\begin{array}{l}\text { Total } \\
\text { weight } \\
\text { gained (kg) }\end{array}$ & $\begin{array}{l}\text { Daily weight } \\
\text { gain } \\
\text { (g/day) }\end{array}$ \\
\hline Natural rangeland & $2.07 \mathrm{a}$ & 2.6 & 3.0 & $1.1 \mathrm{c}$ & $10.7 \mathrm{c}$ \\
\hline Digitaria exilis & $1.83 b$ & 2.6 & 3.0 & $3.0 \mathrm{bc}$ & $42.9 \mathrm{bc}$ \\
\hline Bracharia decumbens & $1.97 \mathrm{ab}$ & 2.3 & 2.8 & $10.0 \mathrm{a}$ & $142.9 \mathrm{a}$ \\
\hline Digitaria decumbens & $0.72 \mathrm{c}$ & 2.6 & $1.2 b$ & $4.3 b$ & $60.7 b$ \\
\hline Significance & $* *$ & ns & $* *$ & $* *$ & $* *$ \\
\hline LSD & 0.145 & 0.32 & 0.25 & 3.21 & 45.70 \\
\hline
\end{tabular}


Table 4: Effect of hay on weight (kg) of yearling Yankasa rams at 2,4,6,8 and 10 weeks of feeding

\begin{tabular}{|c|c|c|c|c|c|}
\hline Hay & Week 2 & Week 4 & Week 6 & Week 8 & Week 10 \\
\hline Natural rangeland & $11.5 b$ & 12.8 & $12.8 \mathrm{~b}$ & $12.3 \mathrm{c}$ & $11.8 \mathrm{c}$ \\
\hline Digitaria exilis & $15.5 \mathrm{a}$ & 15.8 & $16.0 \mathrm{ab}$ & $16.0 \mathrm{~b}$ & $15.5 b$ \\
\hline Bracharia decumbens & $17.8 \mathrm{a}$ & 16.8 & $18.8 \mathrm{a}$ & $19.8 \mathrm{a}$ & $21.0 \mathrm{a}$ \\
\hline Digitaria decumbens & $14.0 \mathrm{ab}$ & 14.8 & $15.8 \mathrm{ab}$ & $15.3 b c$ & $16.0 \mathrm{~b}$ \\
\hline Significance & $*$ & ns & $*$ & $* *$ & $* *$ \\
\hline LSD & 3.90 & 4.11 & 3.87 & 3.71 & 3.18 \\
\hline
\end{tabular}

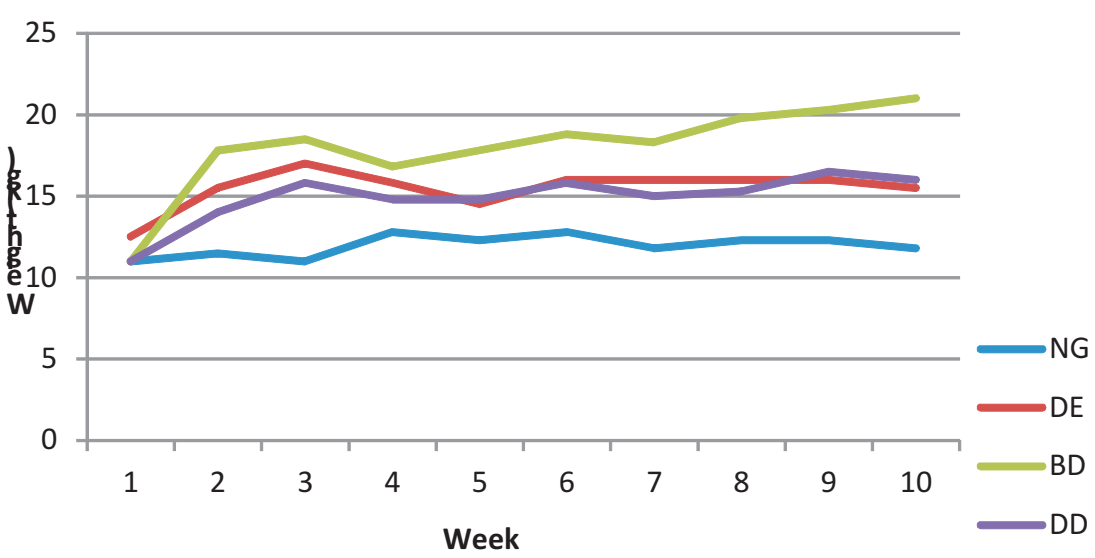

Figure 1:Trend of alternate weight changes in yearling Yankasa rams; $\mathbf{N G}=$ Natural grass, $\mathbf{D E}=$ Digitaria exilis, $\mathbf{B D}=$ Bracharia decumbens, $\mathrm{DD}=$ Digitaria decumbens

ample supply of supplementation to meet their nutritional requirement for maintenance and growth. Supplementation results in better growth and reproductive performance in ruminants (Abubakar et al., 2005; Ocheja et al., 2009). The higher CP concentration of DEH (5.4\%) compared to $\mathrm{BDH}(4.1 \%)$ and DDH (4.9\%) may be due to fertilizer application of the annual grass (Digitaria exilis). It is probable that with fertilizer application, $\mathrm{CP}$ concentrations of the perennial pasture grasses (Brachiaria decumbens and Digitaria decumbens) could significantly surpass that of Digitaria exilis which is not suited to high fertilizer application being primarily a grain crop. Regular additions of nitrogen maintain high forage and protein yields from pastures (Oakes and Skov, 1961). Fertilizer application can enhance the quality of Brachiaria decumbens and Digitaria decumbens grasses and hays for the benefit of ruminant livestock. Moreover, being perennial grasses, Brachiaria decumbens and Digitaria decumbens are capable of providing good quality hays for several years once established. Similar pastures at the National Animal Production Research Institute (NAPRI), Shika-Zaria are over 30 years and still very productive (Kallah, personal communication). On aggregate, the NFE value $(54.2 \%)$ furnished by the hays was quite satisfactory. Carbohydrates 


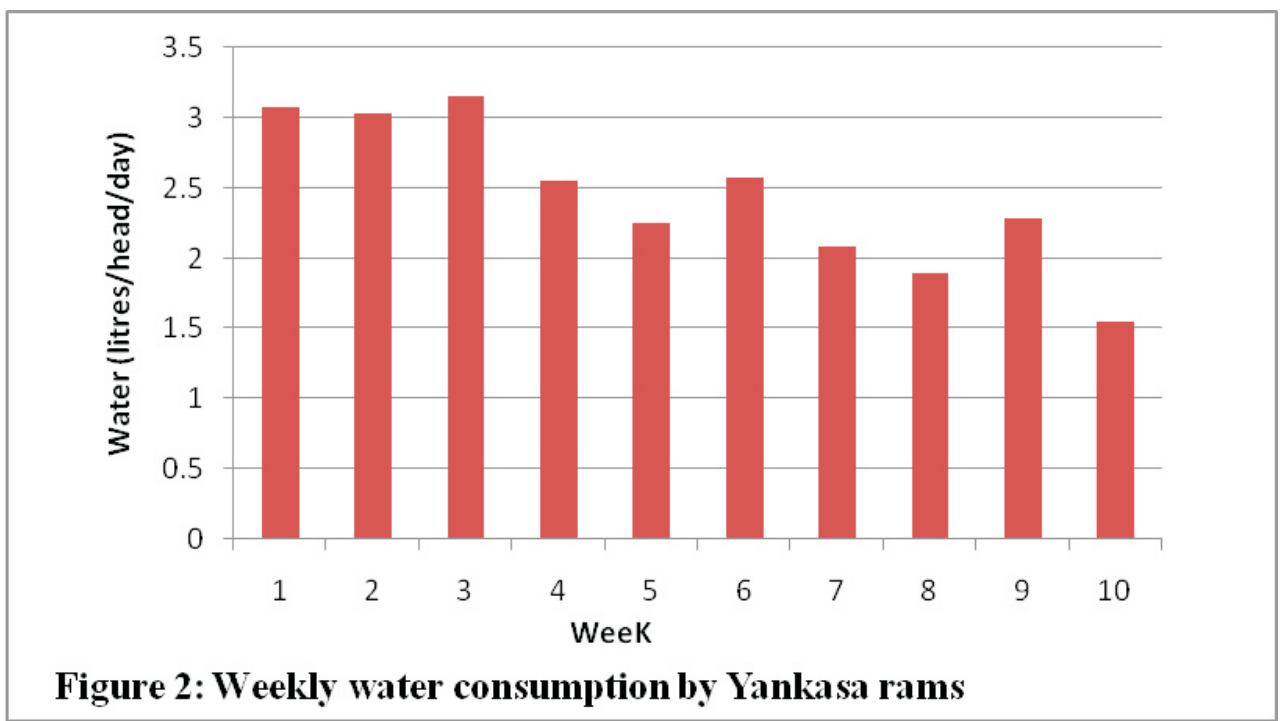

are the main source of energy to ruminants (Johnston, 1983) and Nitrogen free extract (NFE) is a readily available carbohydrate in forages (Van-Soest, 1985). This implies that forages with adequate amounts of NFE may provide useful energy to the consuming livestock.

Generally, hay affected the weekly weight of yankasa rams given the weight increase for animals in all treatments at 10 weeks. This implies that the hays fed, furnished the animals with some of the required energy and $\mathrm{CP}$ for maintenance and growth. Since equal amounts of supplementary concentrate was offered to the experimental animals, the variation in weekly weight was likely due to the hays fed (Ahmed, 2007). This supports the assertion that forage is the major nutritional component in the diets of ruminants (Yashim and Jokthan, 2010). However, the weight increase was not consistent. Slight increase and decrease in live weight was observed in all the treatments during the course of experimentation. The undesirable saw- tooth effect (increase and decrease) in live weight is a common trend in ruminant livestock production in the tropics (Humphreys, 1987), associated with poor quality and insufficient forage (Tarawali et al., 1999). It is noteworthy that one animal in the BDH treatment maintained a uniform weight curve across the 10-week experimental duration. Furthermore, all animals maintained a good body conformation throughout the feeding period. This implies that the hays and concentrate were sufficiently qualitative to provide the confined animals with needed energy for maintenance and growth.

The experiment further revealed that yankasa rams fed with BDH gained more weight at 10 weeks than rams fed with the other hays. Average body weight $(21.3 \mathrm{~kg})$ recorded by rams fed on $\mathrm{BDH}$ is higher than the mean body weight $(20.31 \mathrm{~kg})$ reported for yankasa rams by Akpa et al. (2011). This vindicates $\mathrm{BDH}$ as a suitable feeding resource for sheep and also implies that $\mathrm{BDH}$ was palatable and provided the rams 
with more useful energy for growth compared to the other hays. According to Cooper and Thomas (1986), the value of a food is determined by its metabolisable energy and digestible crude protein. Furthermore, the highest individual weights recorded by animals within hays, which were, $15 \mathrm{~kg}$ in NRH and DDH, $19 \mathrm{~kg}$ in $\mathrm{DEH}$ and $25 \mathrm{~kg}$ in $\mathrm{BDH}$, indicated that rams fed on $\mathrm{BDH}$ gained more weight. This gives further credence to the suitability of $\mathrm{BDH}$ for fattening rams. However, it also indicated that the quantity of feed was insufficient to optimize weight gain. It may be necessary to increase the feed allocated beyond the recommended 2.5-3\% of liveweight (Cooper and Thomas, 1986) which was used as the basis for rationing concentrate to the rams. Moreover, feed should have been increased to complement live weight changes by the rams which was logistically difficult to execute in the current study given the number of pens (20) in which the animals were housed. However, Osuhor et al. (2004) fed yankasa rams at 2, 4, 6 and $8 \%$ of live-weight but found feeding at $8 \%$ uneconomical.

The TWG $(1.1-10.0 \mathrm{~kg})$ by the animals in this study was higher than the TWG (1.5$2.5 \mathrm{~kg}$ ) reported by Ocheja et al. (2009) who carried out a similar study. The difference between the results may be attributed to the feeds (Pennisetum purpureum supplemented with bambara nut and rice offal) and quantity offered ( $150 \mathrm{~g} \mathrm{head}^{-1}$ day $\left.{ }^{1}\right)$ in the former study compared with the various hays provided at $2 \mathrm{~kg}$ head $^{-1}$ day $^{-1}$ supplemented with $200 \mathrm{~g}$ of concentrate per head per day in the present study. According to Aduku (2005), the expected daily weight gain of sheep is $150 \mathrm{~g}$. In this study, the observed daily weight gain was in the range of (10.7- $142.9 \mathrm{~g}$ /day). This variation may be ascribed to insufficient allocation of feed to complement daily weight changes as earlier alluded. On the other hand, weight gain may vary between breeds of sheep, climatic seasons and system of husbandry. Balami breed of sheep have a larger body size than yankasa breed of sheep (Whyte $e t$ al., 2001) and may therefore gain more weight when fed under similar conditions. Weight gain by ruminants is faster in the rainy season when high quality forages abound than in the dry season when good quality feeds are scarce (Tarawali et al., 1999). Sheep in confinement with a limited range of feeds to select from may not gain weight as quickly as sheep under free range grazing with a wide variety of feed choices. Animals in the current study consumed similar quantities of water irrespective of the hays fed. In a similar study by Osuhor $e t$ al. (2004), water consumption (3 liters head $^{-1}$ day $^{-1}$ ) by yankasa rams did not differ significantly among all treatments. However, in this study, rams consumed an average of 2.5 litres of water daily. Difference in water consumption between both studies may be attributed to weather condition and variation in feeds offered. Rams consumed more water during the first 3 weeks of experimentation compared to the last 3 weeks of study. The higher consumption earlier on was probably due to the higher ambient temperature at that time compared to the final 3 weeks which was noticeably cooler due to higher rainfall incidence. In May, June and July, 3.5, 10.2 and $9.1 \mathrm{~mm}$ of rain respectively was recorded in Vom. The implication is that where available, water should be provided ad libitum to animals to aid metabolism (Ocheja et al., 2009; Mubi et al., 2012) but under scarcity, rationing is advocated (Osuhor et al., 2004). The high acceptability of NRH, DEH and BDH but poor acceptability of DDH exhibited by rams, infers that BDH has a bright potential for sheep rearing in Vom-Nigeria. This 
assertion is credible because rams showed equal acceptance for NRH and DEH the more familiar hay and BDH which is just being incorporated into the NVRI farming system. The poor acceptability of DDH by rams may be simply ascribed to unfamiliarity. Previous observations by herdsmen indicated that fresh Digitaria decumbens grass was well grazed by sheep (Umaru-Umaru personal communication). Livestock reject feeds on grounds of unfamiliarity, un-palatability, mode of presentation etc. (Johnston, 1983). It is possible that under continuous exposition, acceptability of DDH by rams may improve.

\section{Conclusion}

The study indicated that with similar supplementation, BDH is superior to $\mathrm{NRH}$, $\mathrm{DEH}$, and DDH for fattening yankasa rams. Rams exhibited similar acceptance for $\mathrm{NRH}, \mathrm{DEH}$ and BDH and consumed equal amounts (2.5 litres head ${ }^{-1}$ day $\left.^{-1}\right)$ of water irrespective of treatment. Establishment of Bracharia decumbens pastures should be sustained for the benefit of sheep and other ruminant livestock at NVRI, Vom-Nigeria.

\section{Acknowledgement}

The authors acknowledge the former Executive Director of National Veterinary Research Institute Dr. (Mrs) L. H. Lombin who actively supported pasture development and provided personnel and inputs for the programme. The authors are also grateful for the technical support provided by $\mathrm{Mr}$ Abdulahi Sajo and for initial manuscript review by Dr. K.E. LawOgbomo

\section{References}

Abubakar, M., Adegbola, T.A. and Abubakar, M.M. 2005. Effects of varying levels of groundnut haulm and cowpea shell on the performance of weaned red Sokoto goats. Nigerian Journal of Animal Production (1 and 2): $274-279$.

Adu, I.F.,Olaloku, E.A. and Oyenuga, V.A. 1974. The effects of energy intake during late pregnancy on lamb birth weights and lactation of Nigerian dwarf sheep. Nigerian Journal of Animal Production 1: 151-161.

Aduku, A.O. 2005. Tropical feedstuff analysis table. $4 \mathrm{pp}$.

Ahmed, M.K. 2007. Special seminar in statistics: Interpretation of Research Results. Department of Agronomy. Ahmadu Bello University, Zaria. 5pp.

Akpa, G.N., Suleiman, I.O. and Alphonsus, C. 2011. Effect of age, hair type and body condition score on body conformation traits in yankasa rams. Nigerian Journal of Animal Science 13:23-28.

Association of Official Analytical Chemists (AOAC). 2000. Official Methods of Analysis. Washington, DC.

Cooper, M.G. and Thomas, R.J 1986. Profitable Sheep Farming. The Garden City Press Ltd. Hertfordshire, Great Britain. 560 pp

Finangwai, H.I., Ehoche, O.W. and Akpu, G.N. 2010. Effect of urea treated maize stover based complete diet on the biochemical changes in the rumen and blood parameters of cross bred bull. In; Ifut, O.J., Iyang, U.A., Akpan, I.P. and Ebeso, I.E. (Eds.). Proceedings of $15^{\text {th }}$ Conference of Animal Science Association of Nigeria (ASAN), 13-15 September 2010, University of Uyo, Akwa Ibom, Nigeria. $677 \mathrm{pp}$.

Humphreys, L.R., 1987. Tropical pastures and fodder crops. Intermediate Tropical Agriculture Series. Longman Scientific and Technical, UK.155pp. 
Johnston, R.G. 1983. Introduction to Sheep Farming. William Collins Sons and Co. Ltd. London. 458 pp.

Maynard, L.A. 1944. The Atwater system of calculating the caloric value of diets. The Journal of Nutrition. 443452.

Mubi, A. A, Zetang, T.E., Midau, A.,Bube, M.M. and Augutine, C. 2012. Performance of red Sokoto goats grazing natural pastures supplemented with maize offal. Adamawa State University Journal of Agricultural Sciences 2 (2) : 88-93.

Oakes, A.J. and Skov, O. 1961. Response of four pasture grasses to nitrogen in the dry tropics. Agronomy Journal 53:176-178.

Ocheja, J.O., Attah, S.A., Daikwo, S.I., Okpe,A.A. and Okpanachi, U. 2009. Performance of growing rabbits fed varying proportions of a mixture of Bambara nut waste and whole sweet potato meal as supplement to natural pasture. Nigerian Journal of Indigeneous Knowledge and Development (NJIKAD) 2: 149-155.

Olubajo, F.O. and Oyenuga, V.A. 1974. The yield, intake and animal production of four tropical grass species grown at Ibadan. Nigerian Journal of Animal Production 1:217224.

Osuhor, C.U., Tanko, R.J., Dung, D.D., Muhammad, I.R. and Odunze, A.C. 2004. Water consumption of yankassa rams fed a basal diet of maize stoverlablab mixture.
Tarawali,S.A., Peters,M., and SchultzeKraft,R. 1999. Forage Legumes for Sustainable Agriculture and Livestock Production in Sub-humid West Africa. International Livestock Research Institute (ILRI). Project Report. ILRI, Nairobi, Kenya.132pp.

SAS (Statistical Analysis System), 2002. Guides for personal computers. Version 9.00(Ed). SAS Institute Inc., Cary, NC.USA.

Steel, R.G., Torrie, J.H. and Dickey, D.A. 1997. Principles and Procedures of Statistics: $A$ Biometrical Approach. $3^{\text {rd }}$ edition, McGraw-Hill Co., New York. 666pp.

Van Soest P.J. 1985. Composition, fiber quality, and nutritive value of forages. pp 412-421. In: Forages: The science of grassland agriculture. Edited by, Heath M.E., Barnes R.F. and Metcalfe D.S. The Iowa State University Press. Ames, Iowa. $4^{\text {th }}$ edition.

Whyte, E.P., Doro, Y. and Joel, M. 2001. Effect of season of lambing on birth weight of ewes lambs in Vom. NVRI Seminar Series 1.20 pp.

Yashim, S.M. and Jokthan, G.E. 2010. Effect of different parts of plant on the nutritive value of Rattle box (Crotolaria retusal) plant. In; Ifut, O.J., Iyang, U.A., Akpan, I.P. and Ebeso, I.E. (Eds.). Proceedings of $15^{\text {th }}$ Conference of Animal Science Association of Nigeria (ASAN), 1315 September 2010, University of Uyo, Akwa Ibom, Nigeria. 677 pp. 